\title{
PENGARUH TATA RUANG KANTOR, LINGKUNGAN KERJA DAN PRESTASI KERJA TERHADAP SEMANGAT KERJA TENAGA KEPENDIDIKAN DI SMKS KRIAN 2 SIDOARJO
}

\author{
Anggi Islamidina Arifin ${ }^{1}$, Siti Sri Wulandari ${ }^{2}$ \\ Universitas Negeri Surabaya \\ 12anggi.17080314002@mhs.unesa.ac.id, ${ }^{2}$ siti.wulandari@unesa.ac.id
}

\author{
DOI \\ https://doi.org/10.26740/jupe.v9n2.p54- \\ 59
}

\author{
Article history \\ Received \\ 3 March 2021 \\ Revised \\ 10 March 2021 \\ Accepted \\ 12 March 2021
}

\section{How to cite}

Arifin, A.I., \& Wulandari, S.R. (2021). Pengaruh Tata Ruang Kantor, Lingkungan Kerja dan Prestasi Kerja Terhadap Semangat Kerja Tenaga Kependidikan di SMKS Krian 2 Sidoarjo. Jurnal Pendidikan Ekonomi (JUPE), 9(2), 54-59.

https://doi.org/10.26740/jupe.v9n2.p54$\underline{59}$

Kata Kunci: tata ruang kantor, lingkungan kerja, prestasi kerja, semangat kerja.

Keywords: office layout, work environment, work performance, work spirit

\section{Corresponding author}

Anggi Islamidina Arifin, anggi.17080314002@mhs.unesa.ac.id

\begin{abstract}
Abstrak
Riset ini memiliki tujuan guna mengetahui pengaruh tata ruang kantor, lingkungan kerja, prestasi kerja semangat kerja tenaga kependidikan di SMK Krian 2 Sidoarjo. Jenis studi yang dipakai ialah penelitian deskriptif dengan memakai pendekatan kuantitatif dengan metode regresi linier berganda. Populasi di riset ini ialah tenaga kependidikan SMKS Krian 2 Sidoarjo dengan jumlah 57 pegawai, namun riset sekadar mengambil tenaga kependidikan yang pekerjaannya berhubungan dengan administrasi, hal ini diberikan penyesuaian dengan output riset. Sampel dalam riset ini ialah purposive sampling. Peneliti mengambil 50 karyawan dari 57 populasi. Hasil penelitian menunjukkan bahwa secara simultan tata ruang kantor, lingkungan kerja dan prestasi kerja berpengaruh signifikan terhadap semangat kerja tenaga kependidikan di SMKS Krian 2 Sidoarjo, sedangkan secara parsial masing-masing variabel berpengaruh signifikan ke semangat kerja staf pengajar di SMKS Krian 2 Sidoarjo.
\end{abstract}

\section{Abstract}

This research purpose to determine the effect of office layout, work environment and work performance on the morale of the teaching workforce at Krian 2 Senior High School Sidoarjo. This type of study is a descriptive study with a quantitative approach with multiple linear regression models. The population in this study was the educational staff of Krian 2 Sidoarjo SMKS, which amounted to 57 employees, but researchers only took educational staff whose work was related to administration, this was adjusted to the research objectives. The sample in this study was purposive sampling. Researchers took 50 employees from 57 populations. The results showed that simultaneously the office layout, work environment, and work performance affect work spirit on the morale of the teaching staff at Krian 2 Sidoarjo SMKS, while partially each variable has a significant effect on the morale of the teaching staff at Krian 2 Sidoarjo SMKS. 


\section{PENDAHULUAN}

Keberhasilan suatu lembaga atau organisasi tergantung pada sebagian besar kegiatan sumber daya manusia yang menjalankan di suatu instansi tertentu. Di instansi terdapat bagian-bagian yang bisa merealisasikan visi dari instansi itu sendiri. Bagian-bagian instansi diantaranya bangunan, fasilitas maupun peralatan kelengkapan kantor, visi dan misi, pekerja dan output. Setiap instansi atau perusahaan perlu memperhatikan komponen-komponen yang terdapat dalam instansi tersebut karena suatu pekerjaan dapat berjalan dengan baik ataukah tidak tergantung dari komponen yang ada pada instansi atau perusahaan tersebut, dan salah satu komponen yang dapat mempengaruhi adalah pegawai. Pegawai memiliki kapasitas yang strategis di instansi maupun perusahaan yakni menjadi pemikir, planner dan controller seluruh kegiatan instansi atau perusahaan. Pekerja ialah asset yang fundamental dalam suatu instansi atau perusahaan guna output suatu instansi atau perusahaan terpenuhi, maka pekerja perlu semangat kerja yang baik guna bisa berjalan lebih baik.

Semangat kerja yang tidak maksimal, disebabkan karena penataan ruang yang kurang maksimal seperti belum menerapkan 5R (Rapi, Ringkas, Resik, Rawat, Rajin), sehingga berdampak pada buruknya konsentrasi karyawan pada pekerjaan. Semangat kerja yang baik akan ditunjukkan dengan motivasi yang tinggi seperti kedisiplinan karyawan. Sedangkan pegawai dengan semangat yang rendah akan cenderung malas, kurang disiplin dan cepat merasa bosan dalam melakukan pekerjaan.

Sebab lainnya lingkungan kerja kurang mendukung seperti nimimnya ruang terbuka hijau yang dapat mengakibatkan tingginya suhu udara di lingkungan sekolah. Selain itu karena salah penempatan kompetensi pegawai yang tidak sesuai bidang yang dilayani, ini akhirnya berimbas pada buruknya pelayanan kepada siswa.

Sekolah Menengah Kejuruan Swasta (SMKS) Krian 2 merupakan sekolah yang ada di kota Sidoarjo dan memiliki 5 keahlian dengan diantaranya Teknik Kendaraan Ringan, Teknik dan Bisnis Sepeda Motor, Teknik Elektronika Industri, Multimedia serta Otomatisasi dan Tata Kelola Perkantoran. Sebagai salah satu lembaga pemerintah di bidang pendidikan, SMKS Krian 2 Sidoarjo diharapkan dapat mengupayakan usaha dalam mencerdaskan kehidupan bangsa. Oleh karena itu, dalam mewujudkannya maka diperlukan kerja sama yang baik antara guru, siswa dan karyawan tata usaha. Seluruh bagian itu diwajibkan bisa bertanggung jawab atas peran masing-masing. Peran administrasi disini juga sangat penting dalam aktualisasi aktivitas-aktivitas itu. Perihal tersebut artinya jika administrasi berjalan dengan baik maka dampaknya aktivitas-aktivitas lingkup akademik maupun non akademik yang ada di SMKS Krian 2 Sidoarjo akan terlaksana dengan lancar seperti keinginan.

Adapun penelitian terdahulu yang dilakukan oleh (Annisa 2015) menjelaskan bahwa semangat kerja dipengaruhi oleh variabel lingkungan kerja, adapun fasilitas dan kondisi kantor dari kualitas penerangan, warna dan pengaturan suhu udara yang terlihat masih kurang untuk membantu pegawai bekerja dengan nyaman. Penelitian lain dilakukan oleh (Anggraeni dan Yuniarsih 2017) menyatakan bahwa tata ruang yang men-support dapat menciptakan para pekerja merasa nyaman dan bersemangat ketika melakukan tugasnya, berbalik yang tata ruang tidak men-support dapat menciptakan pekerja tidak bersemangat dan tidak nyaman.

Sedangkan pada penelitian ini, peneliti memilih melaksanakan riset mengenai semangat kerja tenaga kependidikan yang dipengaruhi oleh variabel tata ruang kantor, lingkungan kerja dan prestasi kerja di SMKS Krian 2 Sidoarjo. Hal ini dikarenakan SMKS Krian 2 Sidoarjo adalah sekolah swasta yang unggul dalam bidang kompetensi keahlian sesuai dengan perkembangan yang semakin modern, guna itu suatu lembaga di dalamnya baik bagian maupun administrasi yang ada di SMKS Krian 2 Sidoarjo bisa terlaksana dengan baik dan salah satu bagian yang bisa mempengaruhi ke proses aktivitas administrasi ialah tenaga kependidikan. Karena tenaga kependidikan wajib mempunyai motivasi bekerja yang baik yang impactnya bisa memperoleh output kerja yang maksimal pula. Tetapi pada kenyataan nya tenaga kependidikan SMKS Krian 2 Sidoarjo belum sepenuhnya mempunyai semangat kerja yang baik, masih banyak karyawan yang kurang cepat tanggap ketika memberi layanan siswa, dan minim terjadi error ketika memberikan layanan.

Sesuai pengamatan yang dilakukan penulis, tata ruang kantor yang diterapkan SMKS Krian 2 Sidoarjo menggunakan tata ruang kantor campuran, dimana masih banyak tumpukan berkas yang kurang tertata rapi. Dengan penataan tata ruang seperti itu, aktivitas yang dilakukan pegawai telihat jelas, konsentrasi para pegawai pun dapat terganggu karena sering sekali karyawan mondar-mandir di sekitar ruang kerja. Sedangkan lingkungan kerja secara keseluruhan yaitu antara ruang tata usaha, ruang kabag, kepegawaian kurang sedikit nyaman dengan sirkulasi udara yang kurang baik. Kurangnya semangat kerja dapat dilihat dari rendahnya tingkat kedisiplinan pegawai saat jam kerja berlangsung, seperti bermain handphone dan mengobrol. Berdasarkan uraian di atas, dalam usaha meningkatkan semangat kerja tenaga kependidikan maka penelitian ini perlu dilakukan. Maka dari itu tujuan dari riset ini ialah untuk mendeskripsikan adakah pengaruh tata ruang kantor, lingkungan kerja dan prestasi kerja terhadap 
semangat kerja tenaga kependidikan di SMKS Krian 2 Sidoarjo.

\section{Tata Ruang Kantor}

Tata Ruang kantor ialah "pengaturan ruangan kantor dan juga penyusunan perabot kantor pada luas ruangan dan ruangan kantor yang ada guna menyediakan sarana untuk para pekerja" (Nuraida 2008). layout kantor ialah setting dan penyusunan semua mesin kantor, alat-alat kantor nan juga fasilitas kantor pada tempat seharusnya, dampaknya pekerja dapat bekerja dengan nyaman, baik, bebas, dan leluasa guna fleksibel. Menurut (Saifuddin 2008) mengatakan jika tata letak kantor semakin baik bagi karyawan maka semangat kerja juga lebih tinggi, sebaliknya jika tata letak kantor tidak bagus bagi karyawan maka semangat kerja bisa menurun. Tata ruang kantor terdiri dari beberapa peralatan dan perabot kantor sehingga dapat menunjang jalannya suatu kegiatan yang dilakukan oleh karyawan. Dengan tata ruang yang efektif maka akan menghasilkan kepuasan bagi karyawan. Perihal itu tentunya dapat terpenuhi semangat kerja. Indikator tata ruang kantor menurut (Asnar 2013) meliputi: 1) Efektifitas tipe layout kantor, 2) Kelancaran sirklus karyawan, 3) Ketepatan ketika penempatan fasilitas kantor, 4) Ketepatan jarak antar pekerja dengan perabotan dan fasilitas kantor, 5) Ketercukupan fasilitas kantor. Indikator tata ruang kantor memiliki artian yang lebih luas sebab dalamnya bagian ruang kerja kantor, dimana ruang kerja kantor ialah bagian berlangsungnya proses kerja dari aktivitas pekerja.

\section{Lingkungan Kerja}

Lingkungan kerja fisik ialah seluruh kondisi dalam bentuk fisik yang berada di sekeliling tempat kerja yang dapat memberi pengaruh pekerja baik dengan langsung ataupun dengan tidak langsung (Sedarmayanti 2009). Menurut (Muchtar 2016) "Lingkungan kerja yang baik itu dimana karyawan dikatakan berkinerja optimal, sehat, aman, dan nyaman”. Sedangkan menurut Sumartono dan Sugito (dalam Inbar et al., 2018)“lingkungan kerja non fisik adalah komunikasi karyawan, hubungan dengan atasan dan lain sebagainya". Lingkungan kerja ialah bagian yang tidak bisa dipecah dari tipe serta lokasi pekerjaan ketika pekerja berkegiatan. Menurut (Wiratama, Mukzam, dan Ruhana 2015) indikator lingkungan kerja ialah : 1) Lighting, 2) Sirkulasi udara, 3) Kenyamanan, 4) Keamanan, 5) Peraturan kerja, 6) Hubungan kerja. Indikator lingkungan kerja ialah sebuah indikator diciptakan guna menkontrol perihal apapun yang di dalam lingkungan kerja. Memakai kontrol perihal itu, maka perusahaan mesti dapat memberikan penyesuaian pada poin-poin yang berada di dalam indikator lingkungan kerja seoptimal mungkin guna dapat menciptakan lingkungan kerja jadi lebih nyaman ketika digunakan oleh pekerja.

\section{Prestasi Kerja}

Prestasi kerja ialah pemberian dorongan ke perilakuperilaku yang dilakukan oleh staff guna memberi semangat ke orang-orang maupun pekerja guna mereka optimal dan bisa menggapai output sesuai yang diinginkan oleh orang-orang itu (Gie 2007). Menurut (Khamri dan Heryanto 2019) mengatakan bahwa ada pengaruh parsial antara variabel prestasi kerja dan semangat kerja yang berarti prestasi kerja berpengaruh positif terhadap peningkatan semangat kerja. Pendapat Siswanto (dalam Kurniawan, 2019) indikator prestasi kerja ialah : 1) Loyalitas, 2) Prestasi kerja, 3) Responsibilitas, 4) Kepatuhan, 5) Jujur, 6) Team Work; 7) Prakasa, 8) Leadership. Pada implementasinya di dunia kerja, seorang pekerja dapat memakai kompetensi terbaik yang dia punyai guna melakukan tugasnya dan saat dia memperoleh output yang baik maka hal itu akan membuat sebuah prestasi di kerjanya.

\section{Semangat Kerja}

Menurut Yulianta (dalam Chandra dan Setiawan 2018) menjelaskan jika semangat karyawan bisa berkembang ketika terjadi suatu relasi yang harmonis diantara pimpinan dengan staff. Terbentuknya implementasi komunikasi organisasi yang baik diinginkan terjadi relasi diantara pimpinan dengan staff yang balance, hingga apa yang diinstruksikan bisa dipahami, direnungkan, dan bisa diimplementasi dengan baik. Semangat kerja ialah sikap mental yang menyiratkan semangat guna melakukan kerja hingga memberi dorongan guna bisa bekerja sama dan bisa melaksanakan kerja tepat pada deadline dengan memiliki tanggung jawab ke pekerjaan yang ditugaskan kepadanya. Menurut (Novianingsih 2013) dan (Annisa 2015) indikator semangat kerja yaitu: 1) Antusiasme, 2) Keaktifan dan keikutsertaan pegawai, 3) Inisiatif dan kreatif, 4) Loyalitas, 5) Kerja sama, 6) Kedisiplinan.

\section{Pengembangan Hipotesis}

Dalam penelitian ini penulis dapat melihat dampak layout kantor, lingkungan kerja dan prestasi kerja ke semangat kerja di SMKS Krian 2 Sidoarjo. Disimpulkan sementara sebab jawaban yang didapatkan baru berdasar dengan fakta-fakta empris yang didapat dari pengumpulan data. Hipotesis dari riset ini ialah :

1. Diduga tata ruang kantor berpengaruh ke semangat kerja tenaga kependidikan SMKS Krian 2 Sidoarjo,

2. Diduga lingkungan kerja berpengaruh terhadap semangat kerja tenaga kependidikan SMKS Krian 2 Sidoarjo,

3. Diduga prestasi kerja berpengaruh terhadap semangat kerja tenaga kependidikan SMKS Krian 2 Sidoarjo 
Berikut adalah kerangka konseptual penelitian :

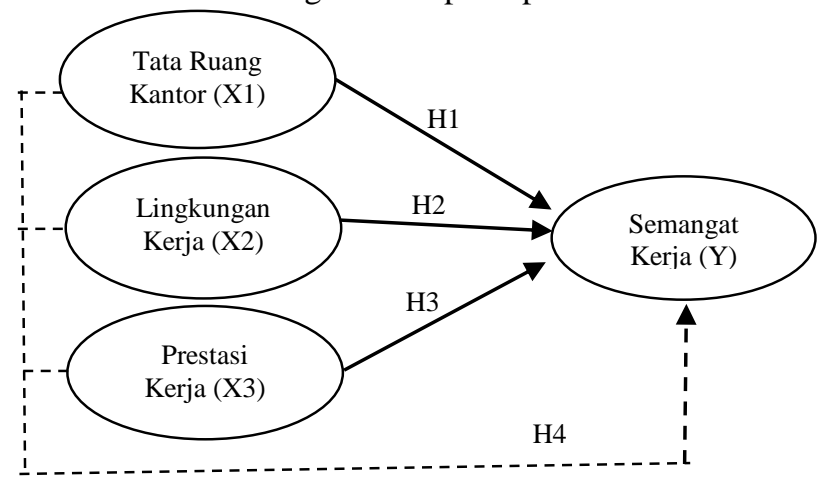

Gambar 1. Hubungan Antar Variabel

Sumber: data diolah peneliti

\section{METODE}

Di riset ini jenis riset yang dipakai ialah riset deskriptif melalui persamaan kuantitatif dengan teknik regresi linier berganda. Gunanya ialah untuk melihat ada atau tidaknya pengaruh antara variabel bebas dan variabel terikat. Variabel penelitian dari penelitian yang akan diteliti adalah semangat kerja (Y) sebagai variabel dependen serta tata ruang kantor $\left(\mathrm{X}_{1}\right)$, lingkungan kerja $\left(\mathrm{X}_{2}\right)$ dan Prestasi kerja $\left(\mathrm{X}_{3}\right)$ sebagai variabel independen.

Populasi dalam riset ini adalah tenaga kependidikan SMKS Krian 2 Sidoarjo dengan jumlah 57 pegawai. Sampel dalam riset ini ialah purposive sampling yakni metode pengambilan melalui evaluasi tertentu yaitu peneliti cuma memakai tenaga kependidikan yang pekerjaannya berhubungan dengan administrasi hal ini disamakan dengan tujuan riset. Peneliti mengambil 50 sampel untuk dilakukan penelitian. Adapun dalam menemukan jumlah sampel, peneliti menggunakan rumus Slovin (dalam Rachman 2016) yaitu sebagai berikut :

$$
\begin{aligned}
& \mathrm{n}=\frac{N}{1+N e^{2}} \\
& \mathrm{n}=\frac{57}{1+57(0.05)^{2}} \\
& \mathrm{n}=49,89 \quad \mathrm{n}=50
\end{aligned}
$$

Dalam penghimpunan data metode yang dipakai guna penghimpunan data yakni kuisioner dengan skala likert. Kuesioner memberikan seperangkat pertanyaan atau pernyataan tertulis kepada responden untuk dijawab. Menurut (Wulandari 2018) instrumen dianggap valid jika nilainya dari $r>0,3$. Sedangkan uji reliabilitas adalah suatu pengukuran keandalan konsistensi internal dengan mencari koefisien alpha $(\alpha)$, Jika alpha Cronbach $>0,6$ maka data penelitian dianggap dapat diandalkan untuk digunakan sebagai masukan dalam proses analisis data. Kegiatan analisis data ini pertama mengelompokkan data, kemudian mentabulasi data berdasarkan variabel, menyajikan data setiap variabel yang diteliti, melakukan perhitungan untuk menjawab masalah dan melakukan perhitungan untuk menguji hipotesis yang diajukan.

Data penelitian dianalisis dengan menggunakan analisis sebagai berikut : 1) uji asumsi klasik untuk meyakinkan bahwa persamaan garis regresi yang diperoleh adalah linier dan dapat dipergunakan (valid) untuk mencari peramalan maka akan dilakukan pengujian multikolinearitas, heteroskedastisitas dan normalitas. 2) Analisis Regresi Linier Berganda digunakan untuk menganalisis pengaruh beberapa variabel bebas atau (X) terhadap variabel terikat (Y) secara bersama-sama. 3) Uji F pada dasarnya menunjukkan apakah semua variabel bebas yang dimasukkan dalam model mempunyai pengauh secara bersama-sama terhadap variabel terikat. 4) uji $\mathrm{t}$ digunakan untuk menguji signifikansi hubungan antara variabel $\mathrm{X}$ dan variabel $\mathrm{Y}$, apakah variabel $\mathrm{X}_{1}, \mathrm{X}_{2}$ dan $\mathrm{X}_{3}$ benar-benar berpengaruh terhadap variabel $\mathrm{Y}$.

\section{HASIL DAN PEMBAHASAN}

Tabel 1 Hasil Uji Reliabilitas

\begin{tabular}{cccc}
\hline Variabel & Cronbac's $^{\prime}$ & Kriteria & Ket \\
\hline $\mathbf{X} 1$ & 0,658 & $>0,6$ & Realibel \\
\hline $\mathbf{X 2}$ & 0,878 & $>0,6$ & Realibel \\
\hline $\mathbf{X 3}$ & 0,852 & $>0,6$ & Realibel \\
\hline $\mathbf{Y}$ & 0,665 & $>0,6$ & Realibel \\
\hline
\end{tabular}

Jadi, sesuai output uji reliabilitas yang ada pada tabel 1 dapat diterangkan jika masing-masing variabel Tata Ruang Kantor $\left(\mathrm{X}_{1}\right)$, Lingkungan Kerja $\left(\mathrm{X}_{2}\right)$, Prestasi Kerja $\left(\mathrm{X}_{3}\right)$ dan Semangat Kerja $(\mathrm{Y})$ memiliki nilai > 0,6 maka bisa diartikan jika pernyataan yang dipakai pada riset ini hasilnya reliabel atau Konsisten.

Tabel 2 Hasil Uji Normalitas

\begin{tabular}{ccc}
\hline & $\begin{array}{c}\text { Unstandardiz } \\
\text { ed } \\
\text { Residual }\end{array}$ & Keterangan \\
\hline Test Statistic & 0,073 & Normal \\
\hline $\begin{array}{c}\text { Asymp. Sig. (2- } \\
\text { tailed) }\end{array}$ & $0,200^{\mathrm{c}, \mathrm{d}}$ & \\
\hline
\end{tabular}

Sesuai hasil uji normalitas pada tabel 2 mempunyai nilai sig sejumlah $0,200 \mathrm{c}, \mathrm{d}>0,05$ yang dapat diartikan data dalam riset ini menyebar secara normal. Salah satu uji normalitas sudah memenuhi persyaratan, maka dapat dilanjutkan ke uji selanjutnya. 
Tabel 3 Hasil Uji Multikolineritas

\begin{tabular}{lccc}
\hline \multirow{2}{*}{ Variabel } & \multicolumn{2}{c}{$\begin{array}{c}\text { Collinearity } \\
\text { Statistics }\end{array}$} & \\
\cline { 2 - 3 } & Kolerance & VIF & \\
\cline { 2 - 3 } Tata Ruang & 0,977 & 1,024 & Non \\
\cline { 1 - 2 } Lingkungan & 0,974 & 1,027 & $\begin{array}{c}\text { Multikolini } \\
\text { eritas }\end{array}$ \\
\cline { 1 - 2 } $\begin{array}{l}\text { Prestasi Kerja } \\
\text { (X3) }\end{array}$ & 0,981 & 1,019 & \\
\hline
\end{tabular}

Dari hasil tabel 3 dijelaskan bahwa nilai tolerance antar variabel Tata ruang kantor $\left(\mathrm{X}_{1}\right)$, Lingkungan kerja $\left(\mathrm{X}_{2}\right)$ dan Prestasi kerja $\left(\mathrm{X}_{3}\right)>0,10$ dari nilai VIF. Maka menunjukkan bahwa dalam penelitian ini tidak ada kesamaan antar variabel bebas di riset ini.

Tabel 4 Analisis Regresi Linier Berganda

\begin{tabular}{llll}
\hline \multicolumn{1}{c}{ Model } & $\begin{array}{c}\text { Unstandardized } \\
\text { Coefficients }\end{array}$ & \multirow{2}{c}{$\begin{array}{c}\text { t } \\
\text { tabel }\end{array}$} & Sig. \\
\cline { 2 - 2 } & \multicolumn{1}{c}{$\mathrm{B}$} & & \\
\hline $\begin{array}{l}\text { Tata Ruang } \\
\text { Kantor (X1) }\end{array}$ & 0,535 & 4,575 & 0,000 \\
\hline $\begin{array}{l}\text { Lingkungan } \\
\text { Kerja (X2) }\end{array}$ & 0,150 & 2,400 & 0,021 \\
\hline $\begin{array}{l}\text { Prestasi } \\
\text { Kerja (X3) }\end{array}$ & 0,159 & 2,045 & 0,047 \\
\hline Dependen variabel $=$ Semangat Kerja & \\
\hline
\end{tabular}

Dari hasil uji regresi pada table 4 diatas maka di ketahui hasil sebagai berikut:

1. Pada variabel Tata Ruang Kantor (X1), nilai signifikansi $0,000<0,05$ yang memiliki arti variabel Tata Ruang Kantor (X1) berpengaruh pada Semangat Kerja (Y) maka $\mathrm{H} 1$ diterima.

2. Pada variabel Lingkungan Kerja (X2), nilai signifikansi $0,021<0,05$ yang memiliki arti variabel Lingkungan Kerja (X2) berpengaruh ke Semangat Kerja (Y) maka $\mathrm{H} 1$ diterima

3. Pada varibel Prestasi Kerja (X3) diketahui nilai signifikansi 0,047<0,05 yang artinya variabel Prestasi Kerja (X3) berpengaruh ke Semangat Kerja (Y) maka $\mathrm{H} 1$ diterima.

\section{Pengaruh Tata Ruang Kantor Terhadap Semangat} Kerja Tenaga Kependidikan SMKS Krian 2 Sidoarjo

Berdasarkan hasil analisa nilai t-hitung X1 4,575 mempunyai nilai signifikan $0,000(0,000<0.05)$. Hingga output dari pengujian tersebut $\mathrm{H} 0$ ditolak dan $\mathrm{H} 1$ diterima, dengan pengertian variabel $\mathrm{X}_{1}$ berdampak ke variabel $\mathrm{Y}$ sehingga hipotesis ke 1 dapat dibuktikan kebenarannya. Tata ruang kantor di SMKS Krian 2 Sidoarjo dari jawaban responden rata-rata masuk dalam kategori tinggi dimana kondisi tata ruang kantor dalam keadaan baik, karyawan dan alat-alat kantor ditempatkan menurut rangkaian yang sejalan dengan urutan penyelesaian pekerjaan. Penataan ruang kantor di SMKS Krian 2 Sidoarjo cukup diperhatikan dan terus berubah mengikuti macam kebutuhan serta kewajiban para pegawai dalam bekerja. Sehingga perubahan penatan tata ruang kantor akan memberikan dampak produktivitas kerja di instansi yang baik dalam bentuk positif dan memberi dampak layanan yang baik ketika dalam proses penyelesaian pekerjaan.

Perihal ini sesuai dari riset yang dilaksanakan dari (Lestari 2019) penelitian ini dilatarbelakangi oleh kurang rapihnya pengaturan tata ruang kantor. Terdapatnya lingkungan kerja yang nyaman, utamanya layout kantor yang baik dapat memberi motivasi ke pekerja guna kerja lebih baik hingga mampu menambah kerja pekerja. Pada penelitian yang dilakukan oleh (Anggraeni dan Yuniarsih 2017) penelitian ini menjelaskan jika layout kantor ialah usaha pengaturan dan penyusunan semua fasilitas kantor di tempat yang sesuai guna para pekerja bisa bekerja dengan baik dan mempunyai rasa nyaman yang tinggi hingga bisat tergapainya efektivitas dan efisiensi kerja pekerja.

\section{Pengaruh Lingkungan Kerja Terhadap Semangat} Kerja Tenaga Kependidikan SMKS Krian 2 Sidoarjo.

Sesuai output uji statistik diketahui lingkungan kerja berdampak ke semangat kerja. Dengan memakai uji $\mathrm{T}$ diperoleh nilai t-hitung 2,400 dan signifikan 0,021 $(0,021<0,05)$. Artinya, variabel $X_{2}$ berpengaruh terhadap variabel $\mathrm{Y}$, dan hasil pengujiannya tersebut $\mathrm{H} 0$ ditolak dan H1 diterima. Maka, hipotesis ke 2 dapat dibuktikan kebenarannya. Lingkungan kerja di SMKS Krian 2 Sidoarjo dari jawaban responden rata-rata masuk dalam dalam kategori tinggi dimana kondisi lingkungan dalam keadaan baik. Hal ini disebabkan karena lingkungan kerja di SMKS Krian 2 Sidoarjo merupakan suatu tempat yang sehat, aman serta menyenangkan.

Perihal ini sesuai dari riset yang dilaksanakan dari (Inbar et al. 2018) penelitian ini bertujuan bahwa dengan terdapatnya lingkungan kerja yang baik dampaknya pekerja dapat termotivasi guna melaksanakan pekerjaan dan tanggung jawab yang didapatnya demi visi perusahaan. Jadi situasi lingkungan kerja bisa memotivasi pekerja, baik dari partner kerja maupun dari pimpinan artinya pekerja akan mempunyai semangat yang tinggi, hingga perihal itu dapat berdampak di penambahan kerja pekerja yang tinggi pula.

\section{Pengaruh Prestasi Kerja Terhadap Semangat Kerja Tenaga Kependidikan SMKS Krian 2 Sidoarjo}

Berdasarkan hasil analisis data diketahui bahwa variabel prestasi kerja berpengaruh terhadap semangat 
kerja hal ini dapat dikatakan karena hasil pengujian diperoleh nilai t-hitung 2,045 dengan nilai signifikan 0,047 $(0,047<0,05)$ yang artinya variabel $\left(\mathrm{X}_{3}\right)$ secara parsial memengaruhi semangat kerja $(Y)$. Dan hasil pengujiannya menerangkan jika $\mathrm{H} 0$ ditolak dan $\mathrm{H} 1$ diterima. Prestasi kerja yang baik akan mendorong timbulnya semangat kerja karyawan. Dengan semangat yang tinggi karyawan akan dapat bekerja dengan perasaan senang sehingga akan berprestasi dalam pekerjaannya. Tenaga kependidikan di SMKS Krian 2 Sidoarjo setiap tahun mempunyai program penilaian prestasi kerja sehingga dapat mengevaluasi dalam meningkatkan hasil kerja yang lebih maksimal karena pegawai dapat mengetahui apa yang telah dicapainya selama kinerjanya serta sebagai bentuk kontribusi kepada instansi hal itu akan dapat nilai plus dalam mendukung prestasi kerja.

Hal ini Sejalan dengan riset yang dilasanakan dari (Inbar et al. 2018) yang menjelaskan bahwa prestasi kerja yang tinggi akan memberi stimulus ke karyawan ketika melaksanakan tugas dengan efektif dan efisien hingga kegiatan di perusahaan dapat terlaksana dengan lancar guna menggapai visi perusahaan. Tanda menurunnya prestasi kerja ini penting dipahami perusahaan guna memahami penyebab turunnya prestasi kerja hingga perusahaan bisa memberi perilaku yang menyebakan menurunnya prestasi kerja di pekerja.

\section{SIMPULAN}

Berdasarkan hasil penelitian tentang pengaruh tata ruang kantor, lingkungan kerja dan prestasi kerja terhadap semangat kerja tenaga kependidikan di SMKS Krian 2 Sidoarjo, maka dapat diambil beberapa kesimpulan yaitu:

1. Tata ruang kantor $\left(\mathrm{X}_{1}\right)$ berpengaruh secara parsial terhadap semangat kerja tenaga kependidikan di SMKS Krian 2 Sidoarjo.

2. Lingkungan kerja $\left(\mathrm{X}_{2}\right)$ berpengaruh secara parsial terhadap semangat kerja tenaga kependidikan di SMKS Krian 2 Sidoarjo.

3. Prestasi kerja $\left(\mathrm{X}_{3}\right)$ berpengaruh secara parsial terhadap semangat kerja tenaga kependidikan di SMKS Krian 2 Sidoarjo.

\section{DAFTAR PUSTAKA}

Anggraeni, Widi dan Tjutju Yuniarsih. (2017). "Dampak Tata Ruang Kantor Terhadap Efektivitas Kerja Pegawai Dinas Pendidikan Kota Bandung." Jurnal Pendidikan Manajemen Perkantoran 2(2):105-12.

Annisa, Noor. (2015). "Pengaruh Lingkungan Kerja Terhadap Semangat Kerja Pegawai Di Kantor Kelurahan Air Putih Samarinda." eJournal Administrasi Negara 3(5):1452-63.
Chandra, Daniel Alexander dan Roy Setiawan. (2018). "Pengaruh Lingkungan Kerja dan Iklim Organisasi terhadap Semangat Kerja Karyawan.” Agora 6(1).

Gie, The Liang. (2007). Administrasi Perkantoran Modern. Yogyakarta: Liberty.chandra

Inbar, Noor Rika Dinata, Endang Siti Astuti, dan M. Cahyo Widyo Sulistyo. (2018). "Pengaruh Lingkungan Kerja Terhadap Disiplin Kerja Dan Semangat Kerja Karyawan (Studi Pada Karyawan PDAM Kota Malang).” Jurnal Administrasi Bisnis (JAB) 58(2):84-92.

Khamri, Aprial dan Heryanto. (2019). "The Influence Of The Work Environment, Work Discipline On The Spirit Of Work And Its Impact On Employee Performance At The Dharmasraya District Health Office." Archives of Business Research 7(5):20516.

Kurniawan, Muhammad. (2019). "Faktor-Faktor Yang Mempengaruhi Prestasi Kerja Karyawan Pada PT. Excelcomindo Engineering Indonesia Sumatera." Jurnal Media Wahana Ekonomika 15(3):39-52.

Muchtar. (2016). "The influence of motivation and work environment On The Performance Of Employees." Sinergi 6(2):27-40.

Novianingsih, Diah. (2013). "Hubungan pengawasan pimpinan dengan semangat kerja pegawai Badan Pendidikan dan Pelatihan Provinsi Sumatera Barat." Jurnal Bahana Manajemen Pendidikan 3(1):43-53.

Nuraida, Ida. (2008). Manajemen Administrasi Perkantoran. Yogyakarta: Kanisius.

Rachman, Mohammad Munir. (2016). Metodologi Penelitian. Surabaya: Adi Buana University Press.

Saifuddin, Muchammad. (2008). "The Effect Of Office Layouts And Leadership Control Towards The Employees Performance In Surabaya." Journal of Applied Management and Administration science 26-31.

Sedarmayanti. (2009). Sumber Daya Manusia Dan Produktivitas Kerja. Bandung: Mandar Maju.

Wiratama, Radhega, Mochammad Djudi Mukzam, dan Ika Ruhana. 2015. "Pengaruh Lingkungan Kerja Fisik Dan Lingkungan Kerja Non Fisik Terhadap Motivasi Kerja Pegawai (Studi pada Pegawai Kantor Pelayanan Kekayaan Negara dan Lelang Malang).” Jurnal Administrasi Bisnis S1 Universitas Brawijaya 27(1):1-10.

Wulandari, Siti Sri. (2018). "Employee commitment and service performance." Human Systems Management 37(4):381-86. 